University of Nebraska - Lincoln

DigitalCommons@University of Nebraska - Lincoln

10-1980

\title{
Myxosoma funduli Kudo 1918 (Protozoa: Myxosporida) in Fundulus kansae (Pisces: Cyprinodontidae): Annual Prevalence and Geographic Distribution
}

\author{
Stephen A. Knight \\ United States Department of Agriculture, Stephen.A.Knight@aphis.usda.gov \\ John J. Janovy Jr. \\ University of Nebraska - Lincoln, jjanovy1@unl.edu \\ William L. Current \\ Targanta Therapeutics
}

Follow this and additional works at: https://digitalcommons.unl.edu/bioscijanovy

Part of the Parasitology Commons

Knight, Stephen A.; Janovy, John J. Jr.; and Current, William L., "Myxosoma funduli Kudo 1918 (Protozoa: Myxosporida) in Fundulus kansae (Pisces: Cyprinodontidae): Annual Prevalence and Geographic Distribution" (1980). John Janovy Publications. 40.

https://digitalcommons.unl.edu/bioscijanovy/40

This Article is brought to you for free and open access by the Papers in the Biological Sciences at DigitalCommons@University of Nebraska - Lincoln. It has been accepted for inclusion in John Janovy Publications by an authorized administrator of DigitalCommons@University of Nebraska - Lincoln. 


\title{
MYXOSOMA FUNDULI KUDO 1918 (PROTOZOA: MYXOSPORIDA) IN FUNDULUS KANSAE (PISCES: CYPRINODONTIDAE): ANNUAL PREVALENCE AND GEOGRAPHIC DISTRIBUTION
}

\author{
Stephen A. Knight, J. Janovy, Jr., and W. L. Current ${ }^{\star}$ \\ School of Life Sciences, University of Nebraska-Lincoln, Lincoln, Nebraska 68588
}

ABSTRACT: The occurrence and distribution of the myxosporidan, Myxosoma funduli, in the plains killifish (Fundulus kansae) were investigated. Samples from sites on the South Platte and Platte River drainages in Nebraska were collected by seining during various months of 1976, 1977, and 1978. At a number of the localities no $F$. kansae were found; the remainder of the collecting sites showed the host population to be abundant, but the $M$. funduli infections to vary in prevalence. The protozoan parasite population in $F$. kansae, upstream from the Nebraska Tri-County Diversion Dam and Canal, at North Platte, Nebraska, demonstrated year-long distributions and intensities similar to those reported for the summer months of 1975 and 1976 (Knight et al., 1977). However, downstream from the diversion dam, prevalence of M. funduli in F. kansae was considerably lower than that observed upstream. The demographic characteristics of the infected fish subpopulation were identical to those of the whole fish population upstream from the diversion, whereas those infected fish downstream from the diversion were too few to establish conclusive demographic results.

A previous study described the occurrence and distribution of the myxosporidan, Myxosoma funduli Kudo 1918, among a population of the plains killifish, Fundulus kansae (Garman), during the summer months of 1975 and 1976 (Knight et al., 1977). This paper describes the prevalence of $M$. funduli in $F$. kansae of the South Platte River in Nebraska throughout an entire year, the parasite's distribution in a sample population of hosts during the entire year, and variation in the parasite prevalence relative to physical characteristics of the portion of the Platte River system studied.

\section{MATERIALS AND METHODS}

Specimens of Fundulus kansae were collected by seining from various sites along the South Platte and Platte rivers in southern Nebraska and transported in a cool, oxygenated tank to either the Cedar Point Biological Station, Ogallala, Nebraska, or to the University of Nebraska campus, Lincoln, Nebraska.

A total of 383 fish was collected from the South Platte River (Ogallala Site) during various months from June 1976 through June 1977. Fish were measured and sexed, and individual gill bars were removed in sequence and examined according to the standardized procedures of Knight et al. (1977). The number of plasmodia per gill bar was recorded for

Received 10 September 1979; accepted 2 May 1980.

* Present address: Department of Zoology-Entomology, Auburn University, Auburn, Alabama 36830 . each host specimen. A total of 111 fish was collected from other sites downstream from the town of North Platte, Nebraska, primarily near the towns of Minden, Kearney, Grand Island, and Silver Creek. Repeated attempts to collect $F$. kansae immediately downstream from North Platte, Nebraska, primarily at Maxwell, were unsuccessful.

Parasite distributions, as number of plasmodia per fish, were fitted to negative binomial distributions according to the methods of Pennycuick (1971), and analysis and interpretations of host demography were made according to the procedures of Minckley and Klaassen (1969).

The physical characteristics of the collection sites were the same as those described by Knight et al. (1977), except for the sites immediately downstream from the Tri-County Irrigation Dam at the town of North Platte. Downstream from this diversion, the river was characterized by greatly diminished flow during most of the year and vegetation that encroached on most of the river bed.

\section{RESULTS}

The distribution of parasites within the "Ogallala" sample expressed as number of plasmodia per fish, for the study months of 1976 and 1977, is shown in Figure 1. The total annual collection was treated as a single sample. The parasite's distribution for the study period appeared overdispersed $(\bar{x}=4.23, s=$ 6.58). Attempts to fit the observed distribution to the negative binomial resulted in the following parameter values: $k=0.3153, r=$ 0.9306. Chi-square tests $(\alpha=0.05)$ showed that the parasite's population distribution could be described by a negative binomial distribution with these parameter values. 


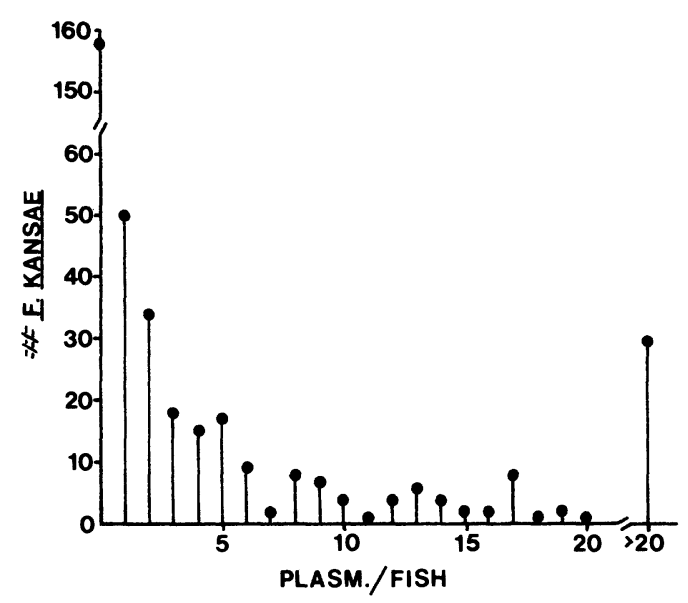

FIGURE 1. Distribution of M. funduli plasmodia among $F$. kansae from the Ogallala Site. All fish collected from June 1976, through July 1977, are included in this graph.

The demographic characteristics of both the total annual sample of fish and the infected subpopulation within that sample for the Ogallala Site are shown in Figure 2. The mean sizes of all collected fish and infected fish $( \pm \mathrm{SD})$, respectively, were $5.45 \mathrm{~cm}(2.49)$ and $5.46 \mathrm{~cm}(2.56)$.

Monthly infection prevalence within the fish collected at the Ogallala Site is shown in Figure 3. The observations for 1976-1977 showed a seasonal fluctuation with lowest prevalence (approx. 20\%) occurring during late July-early August, and highest prevalence (approx. 80\%) occurring during the spring and fall. Figure 3 also shows the monthly size distributions of total fish collected and for the infected subpopulation. The respective size-class percentages of the infected fish subpopulation were nearly equal to those of the total sample per month regardless of the infection prevalence. The most frequently infected fish were those of a size suggesting oldest young-of-the-year $(4.5-5.5 \mathrm{~cm})$ with the remaining 2 nd-year fish $(5.5-7.0 \mathrm{~cm})$ being the next most frequently infected. This distribution of infected fish, according to size classes, is similar to that reported in the earlier study of summer infections (Knight et al., 1977).

The distribution of plasmodia on individual gill bars and the percent infected gill bars found in fish from the Ogallala Site are shown

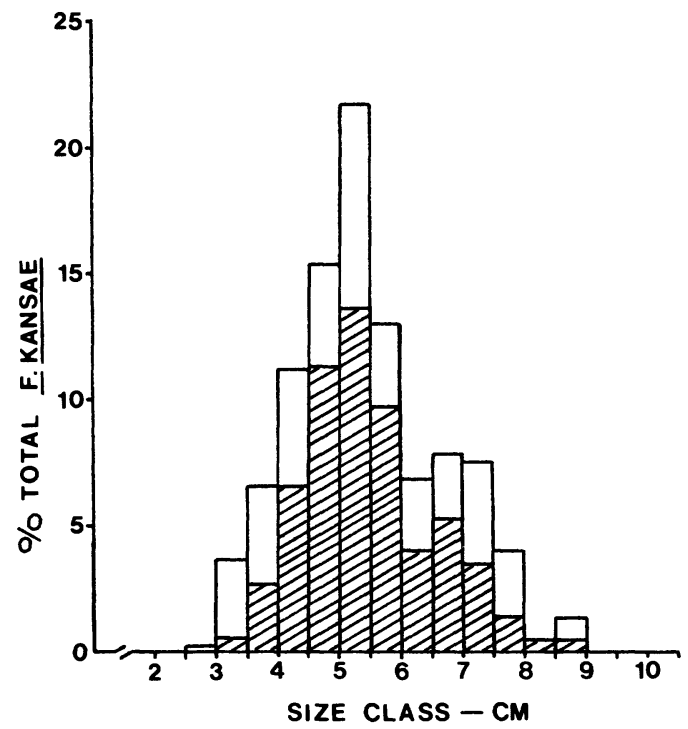

Figure 2. Size class distributions of total fish and infected fish subpopulations collected from the Ogallala Site from June 1976, through July 1977. Open bars-total fish sample. Cross-hatched barsinfected fish subpopulation.

in Figure 4. Although bar numbers 2 and 3, right or left, appeared to have more plasmodia and to be infected more frequently than bar numbers 1 and 4, contingency-table analysis of these data showed that both plasmodium distribution and percent infection were independent of gill bar number or side.

That portion of the South Platte River (Ogallala Site) where the major demographic and epizootic studies of the $M$. funduli-F. kansae relationship were done is shown in Figure 5. Samples from several sites along the South Platte River upstream from North Platte, Nebraska, were pooled for analysis because contingency-table analysis showed that in this portion of the river, infection rate was independent of collection site (Knight et al., 1977). Figure 5 also shows the major physical alteration of the Platte River system in Nebraska, viz., the Tri-County Dam southeast of North Platte, Nebraska. Throughout most of the year, the only water in the Platte River downstream from this dam is seepage, and continuous dredging occurs immediately upstream from the dam itself.

The prevalence of $M$. funduli, and distributions of fish sample size and sex ratios, at collection sites along the South Platte and 


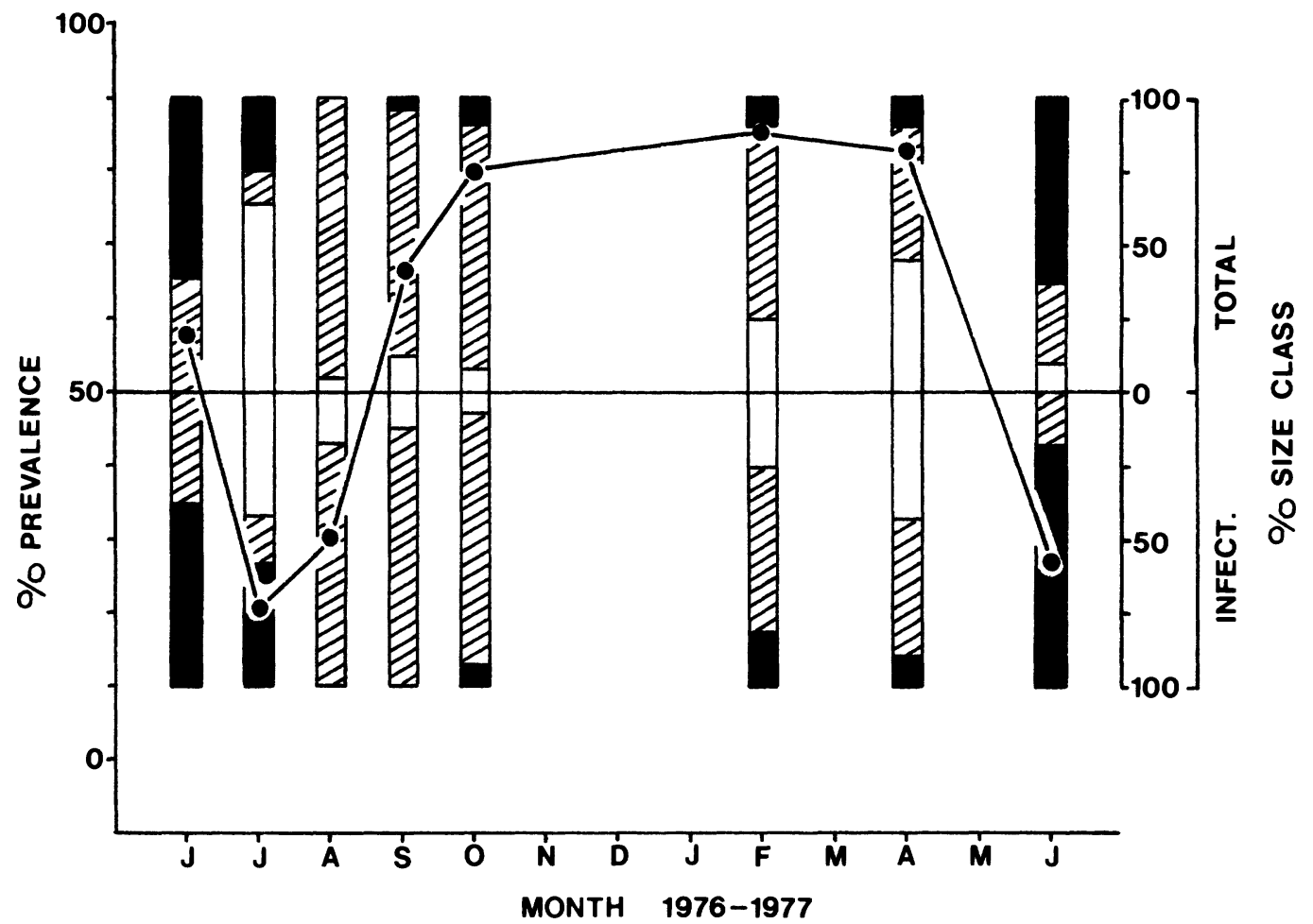

FIGURE 3. Monthly infection prevalence within the total sample and monthly size class distributions of total, uninfected and infected fish subpopulations from the Ogallala Site. Monthly infection prevalence - Monthly size class: open bars: $2.5-4.5 \mathrm{~cm}$; cross-hatched bars: $4.5-6.5 \mathrm{~cm}$; closed bars: $6.5-9.0$ $\mathrm{cm}$.

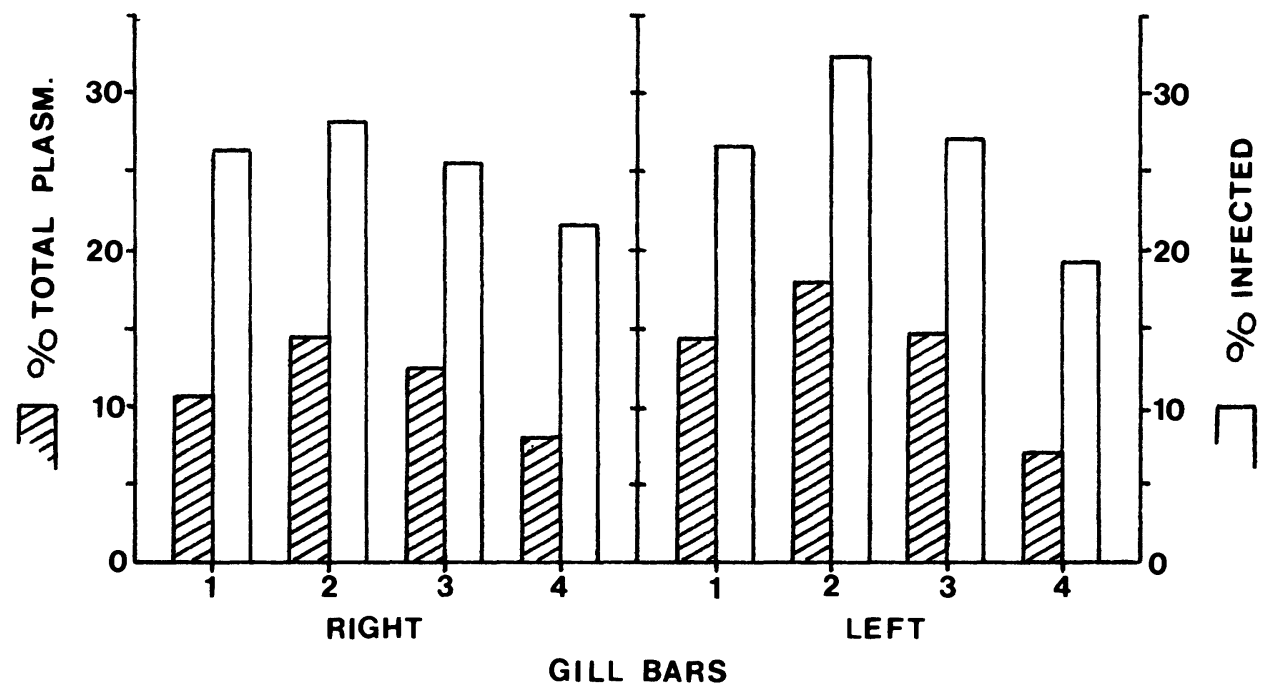

FIGURE 4. Percent frequency distribution of $M$. funduli plasmodia on individual gill bars and percent of total F. kansae gill bars infected from the Ogallala Site. Open bars: percent of total gill bars infected. Cross-hatched bars: percent of total observed plasmodia per gill bar. 


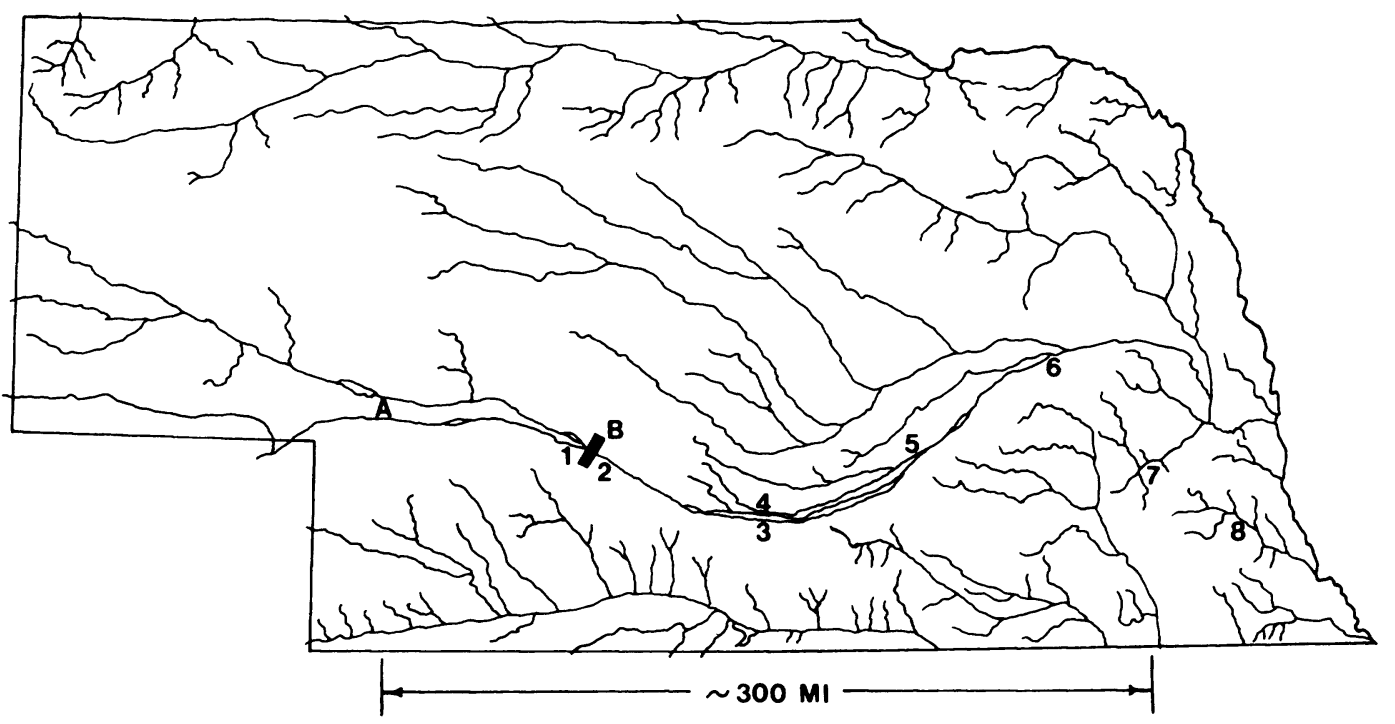

FIgure 5. Collection sites along the South Platte and Platte rivers in Nebraska. A-Ogallala Site (average of five collection sites treated as a single sample). B-Tri-County Diversion Dam. 1-North Platte. 2-Maxwell. 3-Minden. 4-Kearney. 5-Grand Island. 6-Silver Creek. 7-Lincoln. 8-Talmage.

Platte rivers are shown in Table I. The mean prevalence of M. funduli within the F. kansae population sampled over an entire year is $59.1 \%$ upstream from the Tri-County Dam, whereas the mean prevalence downstream from the dam is $5.4 \%$. The mean host size distribution and sex ratios of $F$. kansae collected above and below the dam were not significantly different when subjected to $t$-test analysis $(\alpha=0.05)$, suggesting demographically identical host populations.

\section{DISCUSSION}

The present study has demonstrated that a protozoan parasite population, in the form of plasmodia, is overdispersed within the host population. Hence, the parasite distribution can be described by the negative binomial equation not only during the summer months (cf. Knight et al., 1977), but also throughout an entire year. Secondly, this study demonstrated that although the demographic char-

TABLE I. Myxosoma funduli prevalence (\%), host size distribution ( $\overline{\mathrm{x}} \pm$ SD), and sex ratios (male:female) of fish at various collection sites along the South Platte and Platte rivers.

\begin{tabular}{|c|c|c|c|c|c|c|}
\hline & $\begin{array}{c}\text { Collection } \\
\text { site }\end{array}$ & $\begin{array}{l}\text { No. hosts } \\
\text { collected }\end{array}$ & $\begin{array}{c}\text { Collection } \\
\text { date }\end{array}$ & Prevalence & $\begin{array}{c}\text { Host size } \\
\text { distribution }\end{array}$ & Sex ratio* \\
\hline $\mathbf{A}$ & Ogallala & 383 & $1976-1977$ & 58.8 & $5.39(0.66)$ & 0.63 \\
\hline 1 & North Platte & 25 & $5 / 24 / 78$ & 64.0 & $5.05(0.53)$ & 0.56 \\
\hline B & Tri-County & & & & & \\
\hline 2 & Maxwell & 0 & $3 / 1 / 77$ & - & - & - \\
\hline 3 & Minden & 20 & $3 / 1 / 77$ & 0 & $4.36(0.64)$ & 0.33 \\
\hline 4 & Kearney & 16 & $7 / 27 / 77$ & 6.3 & $4.88(1.29)$ & 0.63 \\
\hline 5 & Grand Island & 42 & $3 / 23 / 77$ & 2.4 & $4.56(0.71)$ & 0.78 \\
\hline 6 & Silver Creek & 13 & $3 / 23 / 77$ & 30.8 & $5.44(0.94)$ & 0.30 \\
\hline 7 & Lincoln & 10 & $10 / 7 / 76$ & 0 & $5.46(0.72)$ & 0.11 \\
\hline 8 & Talmage & 10 & $9 / 28 / 76$ & 0 & $5.74(1.33)$ & 0.80 \\
\hline
\end{tabular}

\footnotetext{
* Calculations do not include those fish that were too small to be sexed, i.e., young-of-the-year.
} 
acteristics of the infected fish population throughout much of the year are generally the same as during the summer months, the lowest prevalence occurs during the middle to late summer (Fig. 3). This drop in prevalence was interpreted to be a result of dilution of the overall infected fish population by youngof-the-year which were either not infected, or were carrying prepatent infections. The increased prevalence shown during early fall suggested a cycle of transmission in which the majority of infected fish entering the winter months was the highly infected (Knight et al., 1977), oldest, young-of-the-year (Fig. 3). Thus, the overwintering success of the parasite may be related to the concentration of the parasite population in the fish with the best chance of surviving the winter.

This study also demonstrated that in contrast to the situation upstream from the TriCounty Dam, prevalence of the parasite below the dam was very low. This observation suggested a possible, indirect manipulation of the host-parasite relationship through irrigation management of the major body of surface water in Nebraska. The North and South Platte rivers converge at the town of North Platte to form the Platte River. At that convergence, flow is interrupted and virtually all the water from the two rivers is sent down the Tri-County Supply Canal to irrigate an area of about 115,000 acres (Bentall, 1975). The yearlong dredging operation behind this dam also clears most of the bed load contributed by the converging rivers from the face of the dam and the mouth of the canal. No major amount of surface water except from farmland runoff is returned to the Platte River for approximately $97 \mathrm{~km}$. Thus it is possible that infective $M$. funduli spores are removed by the dredging operations and distributed across corn fields in southern Nebraska. Water immediately below the dam is primarily seepage and is almost devoid of suspended silt. The observations reported here are consistent not only with those of Sanders et al. (1970), who demonstrated restriction of myxosporidan parasites to certain areas of a river basin, but also those of Cloutman (1975), who showed that variations in lake turbidity could be correlat- ed with diversity of the community of fish parasites within a lake. Although it is difficult to determine absolutely that fish do not occur in a particular portion of a river, repeated failures to collect $F$. kansae directly below the Tri-County Dam suggest that this physical structure helps maintain a separation between two killifish populations demographically similar yet very different relative to parasite burdens.

Detailed explanations of the phenomena observed in these studies must await a detailed description of the life cycle of $M$. fun$d u l i$ as well as a better understanding of spore biology. The present study provides information necessary for analysis of regulatory mechanisms of parasite populations once the life cycle and spore biology have been described.

\section{ACKNOWLEDGMENTS}

We thank Dr. B. B. Nickol, Director, CPBS, for making station facilities available for this research. These studies were supported in part by funds from the University of Nebraska Research Council and the Nebraska Water Resources Research Center.

\section{LITERATURE CITED}

Bentall, R. (Preparator). 1975. Hydrology, Nebraska Mid-State Division, Pick-Sloan Missouri River Basin Program, and associated areas. UNL Conservation and Survey Division, Lincoln, Nebraska, 256 p.

Cloutman, D. G. 1975. Parasite community structure of largemouth bass, warmouth, and bluegill in Lake Fort Smith, Arkansas. Trans. Am. Fish. Soc. 104: 277-283.

Knight, S. A., J. Janovy, JR., AND W. L. Current. 1977. Myxosoma funduli Kudo, 1918 (Protozoa: Myxosporida) in Fundulus kansae: Summer epizootiology. J. Parasitol. 63: 897-902.

MiNCKLEY, C. O., AND H. E. KLAASSEN. 1969. Life history of the plains killifish, Fundulus kansae (Garman), in the Smoky Hill River, Kansas. Trans. Am. Fish. Soc. 98: 460-465.

SAnders, J. E., J. L. Fryer, and R. W. Gould. 1970. Occurrence of the myxosporidan parasite Ceratomyxa shasta, in salmonid fish from the Columbia River basin and Oregon coastal streams. In A symposium on diseases of fishes and shellfishes. Am. Fish. Soc. Washington, D.C., pp. 133-141. 